\title{
ISLAMIC SPAIN IN AMERICAN TRAVEL WRITING
}

\author{
Jeffrey Herlihy-Mera \\ Universidad de Puerto Rico
}

\begin{abstract}
Since the nineteenth century, American travel writers have demonstrated a singular fascination with Andalucía - and with the Alhambra in particular. While Washington Irving, James Michener, and Rick Steves have spilled ink about Granada, their respective views on the palace and its role in the cultures and histories of Spain are remarkably dissimilar. An inquiry still overlooked in studies of American travel writing in Spain concerns why the perceptions of the Alhambra have shifted so drastically since the nineteenth century. The analyses in this article pose a critical framework to contextualize the role of the Alhambra and its cultural histories in the work of these three authors, and offers a theoretical scaffolding on how the cultural symbols of southern Spain have been engaged in travel writing as a method for gesturing toward broader social and cultural positions.
\end{abstract}

Keywords: Travel Writing, Washington Irving, James Michener, Rick Steves, Islam, Andalucía.

\section{LA ESPAÑA MUSULMANA EN LA ESCRITURA DE VIAJES ESTADOUNIDENSE}

\section{RESUMEN}

Desde el siglo XIX, la literatura de viajes norteamericana ha demostrado una fascinación singular con Andalucía -y con la Alhambra en particular-. Washington Irving, James Michener y Rick Steves publicaron textos notables sobre Granada, pero sus respectivas opiniones acerca del palacio y su papel en las culturas e historias españolas son asombrosamente diferentes. Un dilema literario poco estudiado en la crítica de la literatura de viajes estadounidense tiene que ver con el porqué de las diferentes percepciones de la Alhambra tras dichas épocas. Los análisis en este artículo plantean un marco crítico para contextualizar el papel de la Alhambra y sus historias culturales en la obra de estos tres autores; ofrece un andamiaje teórico sobre cómo los símbolos culturales en el sur de España han sido utilizados en la escritura de viajes como método para aludir de forma implícita a posiciones sociales y culturales más amplias.

Palabras clave: literatura de viajes, Washington Irving, James Michener, Rick Steves, islam, Andalucía.

DOI: http://doi.org/10.25145/j.refiull.2019.38.008

Revista de Filología, 38; enero 2019, pp. 125-139; ISSN: e-2530-8548 
Since the nineteenth century, American travel writers have demonstrated a singular fascination with Andalucía - and with the Alhambra in particular. While Washington Irving, James Michener, and Rick Steves have spilled ink about Grana$\mathrm{da}$, their respective views on the palace and its role in the cultures and histories of Spain are remarkably dissimilar. An inquiry still overlooked in studies of American travel writing in Spain concerns why the perceptions of the Alhambra have shifted so drastically since the nineteenth century. The analyses in this article pose a critical framework to contextualize the role of the Alhambra and its cultural histories in the work of these three authors; the argument thus interprets travel writing as a method for gesturing tacitly toward broader social and cultural positions. More precisely, this article argues that the Muslim cultures of Spain are engaged in order to mobilize specific sociopolitical positions contemporary to each author. I contend that the exaltation of Islamic Spain that we find in Irving's Tales of the Alhambra functions as a literary dimension of the Black Legend, an anti-Catholic and anti-Spanish platform imagined as a method for mounting metaphoric resistance to the Spanish Empire in the Americas. A century later, during the dictatorship of Francisco Franco, Michener's approach to Spanish Islam in Iberia: Spanish Travels and Reflections functions as symbolic opposition to the Guardia Mora -a key cultural representation of the totalitarian regime in power. After Franco's death in 1975, the treatment of the Islamic cultures of Spain made yet another diametric shift, this time toward a banal multicultural line, as manifest in Rick Steves's travel books and TV series, in which he presents the Alhambra's histories as neoliberal tourist commodities. In a broader scope, the Islamic symbols and cultural representations that appear in these texts illustrate motivations external to the places -and artefacts- themselves, and gesture toward how travel writing can be a social activity that produces charged politicized documents.

«Travel broadens the mind», write Peter Hulme and Tim Youngs, «and knowledge of distant places and people often confers status» (2002: 2). The writers discussed in this piece aim to contribute to the intellectual cultures of their time, and while status is an inherent part of their motivations, my critique favors the notion of «experience in» rather than "knowledge of». As this argument will make clear, the "knowledges» expressed in these cases often demonstrate an awareness and interaction not with the artefacts in question or the local cultures that they represent, but rather with the organizational logics that the writers bring with them in an a priori sense. In this way, the symbolism of the Alhambra, as it appears in the work of these writers, expresses a lack of knowledge concerning the place and its cultures; but an active participation in the sociopolitical tendencies of the current moment. 


\section{ON THE MYTH OF A MOOR/SPANISH BINARY}

Many understand the Alhambra as symbolic of the apogee of Islamic cultural expression in Spain. The migration of Muslims to the Iberian Peninsula that began in $92 / 711^{1}$ brought languages, traditions, aesthetics, and ways of life that blended into a diverse culture that flourished under Muslim rule for nearly eight centuries (92-897/711-1492). The major advances in science, medicine, architecture, astronomy, and other fields made the cities of Al-Andalus a key center of cultural exchange between Jewish, Muslim, and Christian traditions. For much of the fifth/ tenth and sixth/eleventh century, Córdoba was the most populated urban center in the world. Over half the population in Al-Andalus/Andalucía had voluntarily converted to Islam by 390/1000, and by the sixth/twelfth century, "there were almost no Christian communities left» (Fierro 2005: 207). The Arabic language flourished (and still flourishes) in Al-Andalus/Andalucía among those who remained Christian. Initially there was discrimination vis-à-vis «old»/«new» (دلوم, muwallads) Muslims, though these distinctions disappeared by the fifth/eleventh century. Even today, in the fifteenth/twenty-first century, «many Spanish Muslims do not consider themselves converts, rather... they are reverting» (Roberson 2007: 249).

Founded upon the ruins of a Roman encampment, the construction of the Qal'at al-Hamra or Red Fort (the Alhambra) began during the Nasrid Dynasty (622-897/1232-1492) -the most recent Muslim-majority political body to rule in Iberia. The palace and fortress would house the court and become a cultural center of the kingdom. «The composition of courts, gardens and water», notes Rabah Saoud, «expressed the Muslim views of paradise and its eternality rewarding those who strive to reach it» (2011: 1). Following the Christian conquest of Granada in 897/1492, the complex was kept as a royal residence (the Catholic Monarchs stipulated this in their will) and Charles $\mathrm{V}$ would build a Renaissance-style palace on the grounds. Much of the pre-1232/1492 adornments are inspired by a geometric arrangement with foliage motifs (atauriques) and writings from the Koran.

Despite the intercultural nature of medieval (and contemporary) Iberian society, and the multimodal development of the Alhambra, the terms «Moor(ish)» and «Spanish» often appear as separate, distinct, and unconnected cultural and social entities -a tendency that appears in the writings of Irving, Michener and Steves, as well as some of the critical scholarship about the cultures of Andalucía. This circumstance produces critical language like the following: «Images of the Moor find their way into representations of the Spanish people, Spanish history, and Spanish culture. Indeed, I argue that the figure of the Moor becomes a double in these texts for the space of Spain itself» (Ramos 2011: 41). Reports like this hinge upon a binary linguistic separation between «Spain», «Spanish people» and «Spanish

${ }^{1}$ As a number of dates quoted in this paper refer to historical events that affected both Islamic and Christian Spain, I will hereafter provide them with the dating systems of the Islamic (left) and Gregorian (right) calendars. 
history, Spanish culture» with "the figure of the Moor»; they strive to disassociate blended, interrelated, and shared cultural histories into discrete communities ${ }^{2}$.

Many historical documents from the medieval period oppose the notion that Moor-Christian polarity was a motivation for violence, conquest, or cultural expression. Jaime I of Aragón, upon capturing a region, wrote: «both Christians and Saracens, present and future, are bound to [continue congregating here] for baking their bread» (quoted in Lowney 203). Nor was the invasion of Granada (or the Christian conquest of Iberia more generally) merely a religious intervention. The Tratado de Granada (881/1491) stipulates there would be no conversions; Islamic law would remain in effect; coerced relocation or cultural modification were expressly prohibited; and Arabic would be the official language on public documents. The intercultural resonance is also clear in religious structures (from both traditions): the Court of Lions at the Alhambra has hybrid symbols ${ }^{3}$ and many Medieval Christian temples, even those in the far north of the Peninsula, are adorned by what are often termed Islamic and mudéjar aesthetics. The Monasterio de las Huelgas in Burgos houses the tomb of Doña Berenguela, Catholic Queen of Castile whose funerary headrest was inscribed in Arabic with shahâda (First Pillar of Islam, "There is no God but Allah») and decorated with a figure in a turban and four Rub el Hizbs. The communitive nature of Iberian culture has been, as Chris Lowney argues, "virtually unavoidable» (2006: 203). The Islamic military interventions in the north were similar: when Al-Mansur invaded Compostela in 387/997, he kept vigil at the tomb of Santiago "to protect the site of James the Greater's remains from being sacked. And many other Muslims journeyed to the Christian site» (Moore 2015: 135).

While traditional historical and religious narratives construct binary positions (Islam-Christian), these are not generally representative of the peoples of Iberia or their cultures: "What today, through historical analyses, we consider Islamic Spanish, we put into a political-religious quality of Muslim; this would not occur in the same way at the time of the events. It is likely that many characteristics, forms, symbols, and artistic and cultural fashions that we [today] define as 'Islamic', at that time were considered simply 'Hispanic'» (Momplet Míguez 2008: 126, my translation and emphasis). "Muslim and Christian traditions", as Moore deftly observes, «more than parallel one another: they are overlapping» (2015: 135). It is important to clarify that, in discussion of the cultures of Andalucía, whether or not the patrons, architects, and artists who worked on the Alhambra had Jewish, Christian, Moorish sentiment. Or whether they had a blended, circumstantial, or transitional relation to one, several, all, or another system; or if they were indifferent to such considerations entirely; or if they engaged with them as mercenary goods

2 The term Europeans (or Europenses) was perhaps first used by the Andalusian priest Isidore Pacensis, describing Christians after the battle of Poitiers in 732 (Majid 2009: 4).

${ }^{3}$ Abu Abdullah Muhammad ibn Yusuf ibn Nasr, the original patron of the Alhambra, supported the Christian conquest of Sevilla. 
to secure commissions is unimportant as soon as the critique unpacks the notion of «Islamic/Moorish» as dissimilar from "Christian/Spanish» onto the artefacts ${ }^{4}$.

The slippery ideological positions that these binaries represent are important to contextualize here, as they arise as central points of rhetorical emphasis in texts by Irving, Michener, and Steves. When we examine the experience of each writer and their textual reports, the same terms («Moor»/«Spanish») appear discharged, often without nuance, to lay out a platform to compare and describe, and the mythic binary of Moorish/Spanish functions as the axis of their reflections.

\section{BLACK LEGEND TALES FROM THE ALHAMBRA: RETHINKING WASHINGTON IRVING'S MAUROPHILIA}

The Black Legend - or the myth of Spain as a barbaric, savage place- portrayed Spaniards and Catholicism disreputably in part to curb the expansion of the Spanish Empire in the Americas. Deliberately misinterpreting Islamic, Jewish, and Catholic cultures in Iberia, the Black Legend mythology leveraged US (as well as Dutch, British, French, and other) imperial interests in the western hemisphere, while mobilizing a specific form of anti-Catholic emotion that was already common in US and other Anglo-Saxon cultures. The ways that the Black Legend is codified in cultural spheres is occasionally brutish and nearly always insensitive, though in Irving's Tales of the Alhambra, the use of anti-Catholic sentiment as a literary resource is perhaps most manifest in his selective exaltation of «Moorish» symbols in Granada. While it may appear counterintuitive to align Washington Irving (understood by many critics as a Hispanophile) to Black Legend antipathy toward things Spanish, a close inspection of his Tales of the Alhambra (1832) demonstrates the ways he engaged what he believed to be non-Moorish cultures, languages, architecture, and spiritualties in Andalucía as a focus of derision. Indeed, when we scrutinize his interactions with people who are ostensibly Catholic, and his remarks about the cultures of these communities, his perceptions are forcefully negative.

It is important to emphasize that Irving's interpretation of the cultures of Spain hinges on the aforementioned fictional polarity between Islamic and Christian (as well as Jewish) traditions in Iberia. His particular iteration of Black Legend aesthetics pivots on what he understands as the complete disappearance of so-called Moorish cultures from Spain; this construct allows him to portray and exploit an imaginary Muslim monocultural community vis-à-vis a discrete monocultural Catholic one. Early in the text he takes care to set this structure in motion: «never was the annihilation of a people more complete than that of the Moresco-Span-

${ }^{4}$ While transnational and transcultural theory have dominated scholarship in recent decades, the $\mathrm{A}+\mathrm{B}=\mathrm{C}$ model (and other iterations thereof) has serious flaws: $\mathrm{A}$ and $\mathrm{B}$ are prescribed as discrete and isolated entities, and $\mathrm{C}$ cannot be articulated outside the confines of $\mathrm{A}$ and $\mathrm{B}$. For more on the shortcomings of transnational approaches, see Herlihy-Mera 2018. 
iards» (1832: 28), a fantasy that makes the palace «an elegant memento of a brave, intelligent, and graceful people, who conquered, ruled, and passed away" (1832: 29, emphasis added). This linguistic veil of "passed away" allows Irving to laud the specific cultural relics, architecture, poetry, music, gastronomy, among other cultural material, by labeling them Moorish (meaning, in his register, «not Spanish»). He thus inaugurates a metaphoric apartheid in Andalucían society, portraying the region as sectarian with supposedly different communities with separate traditions, aesthetics and mores, and cultural materials that stem therefrom. Once this segregation motif is in place, Irving exalts «Islamic» cultures through a precise and charged comparison to Catholic traditions, elevating any of his so-called «Moorish» symbols by mocking their «Catholic» equivalents.

Irving had begun using a Moor/Spaniard binary as a literary device as early as 1212/1822 -before he set foot in Spain for the first time. Irving's reflections on Granada and the Alhambra in Bracebridge Hall imagine the palace:

wherein the perpetuity of Moorish power and splendor within these walls was confidently predicted. Alas! How has the prophecy been falsified! Many of the basins, where the fountains had once thrown up their sparkling showers, were dry and dusty. Some of the palaces were turned into gloomy convents, and the barefoot monk paced through those courts which had once glittered with the array and echoed to the music of Moorish chivalry (1822: 251).

Irving ties the Catholic presence to a «dry and dusty» metaphor, while his Moorish equivalent is described as "sparkling showers», and continues: "The fine taste of the Arabs delighted in the sparkling purity and reviving freshness of water, and they erected, as it were, altars on every side, to that delicate element. Poetry mingles with architecture in the Alhambra. It breathes along the very walls» (1822: 251).

In Tales of the Alhambra, Irving's Spaniards (that is, ostensibly Catholic residents of Iberia) do not participate in this splendor: they only bring it to ruin' He understands the Spaniards of his time as Catholics living amid a rich Moorish environment that they have destroyed. Tales of the Alhambra is a thinly-veiled critique of Catholic cultures in Spanish history, one that at times is so contemptuous that it calls into question the nature of Irving's supposed Hispanophilia ${ }^{6}$. In his pattern of praise, Catholic images are a manifestation of backwardness, idleness, lethargy, and indolence, and his fervor for things Islamic adds only depth to this pattern.

Irving's disdain for some aspects of «Spanish» culture (for him, that of the ostensibly Catholic residents of Iberia) is expressed in his scorn of the downfall of the Islamic governments. In a departure from the Islamophobic leitmotif so firmly

\footnotetext{
${ }^{5}$ Irving was in Europe from 1815 to 1832 . He arrived in Madrid in 1826 as a diplomatic attaché. He stayed in the Alhambra from 12 May through the beginning of August 1829.

${ }^{6}$ Irving was a great connoisseur of Spanish cultures, literatures, and histories -his reading of Ginés Pérez de Hita's Guerras Civiles de Granada $(1595,1619)$ may have motivated him to write about peninsular issues.
} 
established in western literatures ${ }^{7}$, Irving faults Catholic Spain for «The downfall of that brilliant dynasty» (1832: 395). The critique he levies concerns not only the expulsion of Moorish political elites but also the upkeep of Islamic cultural symbols -in particular the Alhambra. «The desertion of the [Spanish] court», maintains Irving, "was a fatal blow to the Alhambra. Its beautiful walls became desolate, and some of them fell to ruin; the gardens were destroyed, and the fountains ceased to play. By degrees the dwellings became filled with a loose and lawless population» (1832: 17). Since then, the grounds have been the lair of «thieves and rogues of all sorts» (1832: 17).

Amid this derision for the Catholic Spanish treatment of the palace, Irving praises the French invasion and the arrival of Napoleonic forces: «this monument of Moorish elegance and grandeur was rescued [by the French] from absolute ruin and desolation» (1832: 18). Since the departure of French troops, with the palace again under Spanish custody, the only future is «certain decay» (1832: 18). While the Catholic tradition is also common among the French, including those who occupied Spain in the years he references, they are immune from his searing critique, as the target of Irving's Black Legend derision-through-comparison are Catholic Spaniards.

As he strolls through the courtyards and salons of the palace, Irving believes the Catholic additions to the architecture and art are an «arrogant intrusion» (1832: 22). As he walks from what he understands as the Catholic area into the Moorish, he believes «the transition was almost magical» (1832: 22). The section subheaded "On the Moslem Domination of Spain" goes into some detail about what he feels is an «almost magical power» (1832: 30). His acclaim for the Moors is superlative in nearly all matters, believing that they «sought in Spain to establish a peaceful and permanent dominion» one that is «equitable laws, diligently cultivating the arts and sciences» (1832: 31). He calls it the "greatest civilization» that «diffused the light... of knowledge through western regions of benighted Europe» (1832: 32). All of these were implicitly and explicitly destroyed by Catholic Spanish ignorance and their vile expulsion of Islamic traditions.

To engage the Catholic malevolence to another degree, he sides with «unfortunate Boabdil» (1832: 27), and takes to mentioning incredulity at the crimes committed in the palace. He comments that there are «some who doubt the whole truth» of the story of beheadings that took place there (1832: 23) and believes there is the "vengeance of Heaven on their destroyer" (1832: 24). Irving maintains that the architecture of each culture is metaphoric of their value, noting that the visitor should behold the Moorish brilliance and «contrast it with the ... gloomy solemnity of Gothic edifices» a distinction that, for Irving, «bespeaks the opposite and irreconcilable nature» of Muslim and Catholic Spain (1832: 31).

7 The Poem of the Cid, The Song of Roland, Othello: The Moor of Venice, among many other works in the Western Canon, hinge on the supposed foreign and malevolent nature of Islamic peoples in Europe. 
Irving's descriptions of Catholics is perhaps the most insolent and condescending dimension of the text. He remarks that the «tattered garb» of Mateo, a man who is dignified in manner and interaction with Irving, «befitted the progeny of a ruin» (Irving 1832: 20). While Mateo Ximenes is portrayed as a fool who forgets his family origin, Irving also mocks his father, a man who sleeps in «a crazy bed» and is surrounded by family lineage documents that «he cannot read» (1832: 48). Irving is puzzled that Mateo and people like him (Catholics, in all cases) «appear to enjoy their existence» (1832: 48). The weight of his anti-Catholic prejudice comes out with particular force in his reports of their religiosity: while "they possess nothing, they do nothing, they care for nothing» and are «idle all week», they are "observant of all holy days and saints' days as the most laborious artisan» (1832: 49).

After eviscerating the Spanish for abandoning the palace, Irving remarks, he "longed to ensconce [him] self in the very heart of the building» (1832: 41). The pleasant area, used for a time by the Spanish royalty, had since been "walled up" (1832: 42) by the Spanish. When he reflects on Queen Elizabetta's stint in the same chambers, he considers her presence as «a perversion of fancy, [which] added to the gloom» (1832: 43). What he believes should be treasured, under Spanish tutelage has become "grotesque» and "the nestling place of the beggar» $(1832: 47,46)$. Dolores, a housemaid, warns him of the hazards of certain areas at night. He ignores this advice and dismisses her munificent knowledge as "ravings of a poor maniac» (1832: 44). Amid this danger, despair, negativity, and decay, he declares: «I resolved to brave it» (1832: 44) and goes on a solitary journey through the palace at night. Away from tawdry and superstitious Catholics, the presence of whom he loathes, he is able to appreciate the Alhambra's true grandeur. Away from Catholics, he feels enveloped «in a halo of light» (1832: 44).

As Pere Gifra-Adroher points out, «Wavering between history and romance in a text liable to be read as an ethnographic account, Irving makes the palace of the Alhambra stand for the whole country» (2000: 124). Indeed, the ways that Irving contextualizes Moorish delight with what he terms the "grotesque» Catholic presence, he also succeeds, as Gifra-Adroher deftly comments, in "constructing Spain in terms of a grandiose medieval past bound to a permanently primitive present [Catholic] people with tattered hidalgos in the timeless setting of the Alhambra» (2000: 123). Irving wrote for a Protestant and largely secular readership, «to whom the grandeur of the Moors", notes Boyd Tonkin, «served as another stick to beat the barbarity of old Catholic Europe» (2013: 207). Irving is committed to developing a literary dimension of the Black Legend by engaging a mythic Islamic-Catholic polarity in order to tease out new ways to celebrate the anti-Catholic and anti-Spanish sentiment of his era ${ }^{8}$.

8 While Irving's take on Islamic Spain differs diametrically from American travel writing in the twentieth century, his attack on Catholic culture and exaltation of Islam was not merely another layer of the Black Legend; it also accorded with the warm political policies that the United States had with Muslim nations during his lifetime -in fact, when Irving was a boy, Morocco was the first nation to recognize the independence of the United States. 


\section{ON JAMES MICHENER'S ANTIFASCIST ISLAMOPHOBIA}

While Washington Irving engages the symbols of the Alhambra to degrade the cultures of his contemporary (ostensibly Catholic) Spaniards, James Michener's Iberia has a vastly different take on the role of Islamic cultures in Iberia, one that does not exalt the Moors but instead vitiates their presence in Spain as a "dreadful» event. It is somewhat curious that Michener, who was a lifelong admirer of Islamic cultures and traditions, unpacks such an Islamophobic interpretation of Andalucía; but this attitude can be understood with a contextualization of his political stances concerning the Spanish government when he visited Spain.

Michener calls himself «sympathetic to the Muslim view of life» (1968: 223) -and he spent over two decades in majority-Muslim regions, including Java, Pakistan, Afghanistan, and Turkey. He believed he had spent more time in the Islamic World than any other American writer ${ }^{9}$. In addition to publishing a sympathetic biography of Mohammed, he authored «Islam: The Misunderstood Religion» in Reader's Digest, describing it as a spiritual system that "deserved poetic understanding» (quoted in May 2012: 123). Nevertheless, in Iberia, he is devoted to framing Islam in Spain as a superficial and trivial event, one that has wrought many negative consequences for the Spanish people. Given the context in which Michener visited Spain and published Iberia (the first edition appeared in 1968, seven years before Franco's death), his sentiments toward Andalucía can be understood as motivated in part by an animosity toward Francisco Franco. Aware of the difficulties that would arise if he openly criticized Franco, Michener used the Islamic symbols in his book as a method for disparaging the presence of the dictator. (The book was still banned in Spain when it appeared).

Franco celebrated Moorish images and cultures in his state propaganda. His personal body guards, the Guardia Mora, or Moorish Guard, were a group of elite shock troops who were the central image -literally surrounding Franco- in state ceremonies; they would become symbolic of the regime as a whole (Velasco de Castro 2014: 191). "Moorish guards are Franco's power and protection», notes Bush-Fekete, a traveler in Spain in that period. Their image was everywhere, from the "Hendaye-Irun customhouse» such a «likeness -in bold, black paint- stared at us, condescending, smug and avuncular from thousands of white, yellow or rust-colored walls all over Spain» (Bush-Fekete 1948: 6). The Guardia Mora cavalry squadron appeared in Moroccan cavalry vestments, including the sulhan, alquicel, and turbans. Franco himself had close personal ties to Islam, having spent over a decade in Morocco. In addition to engaging Islamic symbols in his propaganda campaigns, he prohibited the publication of negative images of Muslims or Islam in Spain during his reign. The dictator's daughter, Carmen Franco, recalled that her father «had much respect for Islam» and when members of the Moorish Guard

\footnotetext{
${ }^{9}$ For more on Michener's biography see May 2012.
} 
married Catholic women, he did not compel them to convert to Christianity (quoted in Nordbruch 2014: 220).

Michener's disapproval of Islamic symbols of Spanish culture, and his comments on the supposedly negative outcomes that Muslims had brought to Spain, served as a rhetoric of resistance to Franco's totalitarian violence. He achieves this in part by orienting the discussion of Islam in Iberia as a passing inflection in Spanish cultures and histories, characterizing the eight centuries as an «extended experience»; this notion of «experience» superficializes the role of Islam, a myth further developed by Michener's repeated use of the term «occupation» (1968: vi, 199, 223, 230, $274,927,953)$. The erudite Michener makes frequent reference to previous travel writing on Andalucía, including a comprehensive discussion of both Louis Bertrand and Washington Irving's work. He echoes Bertrand's conclusion that «Muslim domination was a great misfortune for Spain» (1968: 226) and compares Irving's Islamophilia with Bertrand's loathing of things Islamic: «If I were forced to choose between the sentimentalities of Washington Irving and the hard analysis of Louis Bertrand, I would choose Bertrand» (Michener 1968: 226). In doing so, Michener launches a subtle salvo against Franco, whose government actively engaged Moorish symbols. He goes on to note that "on one point [Bertrand] is eminently sound: Spain's proved incapacity to govern herself». He asserts that this «is due primarily to her extended experience with Muslims» (1968: 226, 227).

Like Irving, Michener's discussion relies on the mythic binary of those whom he labels «Spaniards» and "Moors», rejecting the notion that Islamic peoples could be understood as Spaniards: «no reconciliation of Spanish ideals and Moorish was possible» (1968: 227). For Michener and Irving, the Moor is not Spanish (and vice versa), and while Irving celebrated the profundity of the Islamic footprint in the area, Michener has invested in the myth that Islamic traditions had a superficial, if not negligible, influence on Andalusian cultures. Sold to the notion of inconsequential Islamic cultures in the area, Michener found the Alhambra to be «much more Muslim than I had anticipated» (1968: 220). The author uses his reports on the palace architecture to reiterate what he feels is the impermanence of the Muslim "occupation"; he is «surprised at the flimsy construction" that had been "put together with such contempt for permanence» (1968: 222). Aligning what he believes transitory construction methods with the Islamic cultures of Spain, he permits this indirect form of derision and degradation to stand alone as an ostensible report on the architecture. He disdains the palace as «nothing but stucco» that was constructed "as one would build up the decoration of a wedding cake» (1968: 222). That the palace still exists under what he asserts is poor craftsmanship «is astonishing» to Michener; due to the «fragile» nature of the engineering; for him «the surprising thing is that any Muslim remains have survived» (1968: 222).

While Irving uses Catholic symbols to denote gloom in comparison to a delightful Moorish civilization, Michener describes the so-called Islamic elements with disregard, but finds the Courtyard of Lions (realized in hybridized aesthetics, with some Catholic symbolism) to be «a pure work of art» (1968: 222). His overall impression of the palace, like his take on Islam in Spain, is wanting: «it takes someone like the Alhambra architect to slap together disparate items» (1968: 222). 
Michener's reports on the art and architecture of the palace allude to what he calls the "Muslim occupation" (1968: vi, 223, 230, 274, 953); yet, on one occasion he gestures to a permanent imprint of Muslim cultures on the people and their history. He links this cultural root to Spanish expansion in the Americas: «It is this dreadful heritage» with Islam «that keeps Spanish republics of our hemisphere in confusion» (1968: 227). His assertions conclude that «Spain's proven incapacity to govern herself» was due to an "extended experience with Muslims» (1968: 227). When we read these passages in light of Michener's implicit critique of all things revered by Franco, it is clear why his travel book could not -and did not- pass the censors ${ }^{10}$.

\section{NEOLIBERAL TRAVEL WRITING AND RICK STEVES'S "MOORISH» DELIGHTS}

By the 1990s, Black Legend mythology and the symbolism of Franco's Guardia Mora were obsolete and Andalucía was accelerating into a prime tourist destination for upper-middle-class Americans. By the end of the twentieth century, tourism in Spain represented around 12\% of GDP -with over a million American tourists arriving each year. Travel writer and television personality Rick Steves writes travel books and co-produces a television program that airs on PBS; he has stated that he does not earn money from his travel books or travel series Rick Steves Europe, but rather from selling bus tours. As recent retirees and people in their 50 s and 60s are the main customers on these tours, the ways Andalucía and the Alhambra appear in his books and documentaries speak to his understanding of how to appeal to the desires of these demographics. Using his books and television program as advertising for his tours, Rick Steves's 11-to-17-day bus excursions cost \$200-350 per day, excluding airfare.

In order to sell the idea of Spain and Andalucía, Rick Steves's work repackages the images thus far discussed under the guise of inviting multicultural clichés that will offer "a delightful mix of both its Moorish and its Christian past» (Steves 2010). Certainly, Rick Steves's work represents a new phase of American travel writing, one that posits banality and noncritical views in order to encourage people to purchase vacations. «In the absence of critique», notes María DeGuzmán, "the question arises as to what is at stake» (2005: 217). What appears in Steves's travelogues is consistent with what is at stake in a neoliberal environment -that is, his intention to attract customers. Highlighting a blend of historical and entertainment activities, his discourse is carefully constructed in ways that avoid debatable

10 At one point, Michener describes the Plaza Generalísimo Franco in Tordesillas, observing that "grass grew in the corners. Forty-four awkward stone pillars supported an arcade which in places threatened to collapse, while many of the houses fronting on the plaza showed walls that had to be propped up with poles. Several had been patched with cheap stucco painted to simulate concrete block, and all needed painting. Such women as appeared tended to be dressed in black; they worked while their men in patched pants lounged in the shade» (1968: 510). 
topics, favoring the commonplace language of multicultural integration as a way to market Andalucía:

Rick Steves [sic] guide will treat you to a sumptuous, two-week cultural buffet -with rich helpings of ... the Moorish and royal treasures of Granada and Sevilla. You'll also experience the delights of whitewashed Andalusian hill towns, prancing horses, tasty tapas, and fine sherry. Join us for the Best of Spain in 14 Days! (Steves 2018a).

The listed attractions include:

Granada Royal Chapel $\bullet$ Alhambra palace $\bullet$ Ronda bullring $\bullet$ Reservaatauro bull farm $\bullet$ Olive oil tasting $\bullet$ Andalusian horse farm $\bullet$ Sherry tasting $\bullet$ Sevilla walking tour $\bullet$ Sevilla Cathedral $\bullet$ Sevilla Alcázar $\bullet$ Sevilla carriage ride (weather permitting)

- Flamenco performance....and more (Steves 2018a).

Steves offers a form of experiential travel, an approach that focuses on connecting one's visit to the cultures, histories, peoples, and their gastronomic uniqueness -always presenting the cultural artefacts in a limited and prosaic way that allows all comers to engage with them. The platitudes characteristic of this type of advertisement inform readers of specific superficialities; they receive just enough information so that their interest results in a vision of themselves in a banal, appealing environment compiling a new «experience» (and some limited knowledge), so that she or he purchase a tour. The «knowledge» compiled, however, is pointedly reduced to limits that allow the upper-middle-class traveler to have their expectations and pre-existing sensibilities unchallenged.

There is a unique thematic shift in Steves's work that is worthy of note. While Irving's and Michener's take on the cultures of Andalucía, relying on the mythic binary of «Moor» and "Spanish», his work -at least in some instances- describes these systems not as relics, but ongoing. On Granada, for instance, he writes: «Taste the treats of a North African-flavored culture that survives here today» (2018b) and "Home to the magnificent Alhambra palace and still-pungent North African culture» (2018c emphasis added). The temporal qualifier «still» depicts the contemporary local traditions as both explicitly multicultural -and acknowledges that seldom are they recognized as such.

However, Steves's ostensible acceptance of the diversity of contemporary Andalucía has limits. When he discusses the city's «exotic Moorish quarter» and describes the location as «Granada: Moor than the Sum of Its Parts», he re-fetishizes «Moor» as both «exotic» (i.e., «ex», or «out of» normalcy) and signaled out for emphasis in this pun. Moreover, Steves participates in the traditional structural exclusion of an integral component of Andalusian traditions (2018d). While his commentary may selectively gesture toward a cultural pluralism in which various traditions enter into a collaborative dialogue with amalgamative qualities, a central thrust of his promotions reengages the traditional myth of a Moor/Spaniard binary. Like Irving and Michener, rather than examining the area as negotiated histories with cultural material that, despite being supposedly Christian or Islamic (and regardless of the background of the artists, engineers, patrons, architects, and intended public), blend 
aesthetics and components in a way that contradicts the monocultural (and some transnational) myths, it is simpler and more eye-catching for Steves to single out the Moor as foreign:

Moorish magnificence blossomed in the Alhambra. Their visual culture was exquisite, artfully combining design and aesthetics. Rooms are decorated from top to bottom with carved wooden ceilings, scalloped stucco, patterned ceramic tiles, filigree windows, and colors galore. And water, water everywhere. So rare and precious in most of the Islamic world, water was the purest symbol of life to the Moors. The Alhambra is decorated with water: standing still, cascading, masking secret conversations, and drip-dropping playfully (2018d, emphases added).

Although it is somewhat unclear what group functions as the opposition to «their» (the unmentioned «our» could be Spanish, European, American, Christian, Catholic, and so on), the linguistic externalization of Moors through this charged possessive adjective insinuates the conventional binary, indicating that, to Steves, the image of the (supposedly non-local) Moor functions as a useful commodity to market for tourists.

The shifting role of the cultures of Andalucía in these texts demonstrates to a certain degree how travel writing as a genre is a multinodal exercise. That is, one that involves interpretation and filtration of several systems of meaning: the systems of meaning that the travelers bring with them -in this case from the United Statesinfluence and sometimes inform in profound ways the understandings expressed about the places visited. While travel and travel writing are often described as a form of individual wayfinding, as the argument here makes clear, the contemporary social contexts can have important consequences on the "way» that is ultimately found through the travel experience. Indeed, the circumstances from which each author constructs his account of Andalucía and the Alhambra allows these travelogues to play a participatory role in the sociopolitical trends of a particular epoch, and the weight of these politicized, external-to-Spain contextual matters appears to have had a profound influence on the aesthetic experiences of each traveler.

Recibido: junio de 2018; ACEPTAdo: octubre de 2018. 


\section{BIBILIOGRAPHY}

Bush-Fekete, L. (1948): «The Long Night in Franco’s Spain», Life, 11 October, 6-11.

DeGuzmán, María (2005): Spain's Long Shadow: The Black Legend, Off-Whiteness, and Anglo-American Empire, Chapel Hill: University of North Carolina Press.

Fierro, Maribel (2005): «Mawālī and muwalladūn in alAndalus», in Monique Bernards and John Abdallah Nawas (eds.), Patronate and Patronage in Early and Classical Islam, New York: Brill, 195-246.

Gifra-Adroher, Pere (2000): Between History and Romance: Travel Writing on Spain in the Early Nineteenth-century United States, Madison: Fairleigh Dickinson University Press.

Herlihy-Mera, Jeffrey (2018): After American Studies: Rethinking the Legacies of Transnational Exceptionalism, New York: Routledge.

Hulme, Peter and Tim Youngs (2002): «Introduction», in Peter Hulme and Tim Youngs (eds.), The Cambridge Companion to Travel Writing, Cambridge: Cambridge University Press, 1-17.

Irving, Washington (1822): Bracebridge Hall; Or, The Humorists, Volume 1, London: John Murray.

Irving, Washington (1832): Tales of the Alhambra, Paris: Baudry's European Library.

Lowney, Chris (2006): A Vanished World: Muslims, Christians, and Jews in Medieval Spain, Oxford: Oxford University Press.

MajID, Anouar (2009): We are All Moors: Ending Centuries of Crusades Against Muslims and Other Minorities, Minneapolis: University of Minnesota Press.

May, Stephen (2012): Michener: A Writer's Journey, Norman: University of Oklahoma Press.

Michener, James (1968): Iberia: Spanish Travels and Reflections, New York: Random House.

Momplet Míguez, Antonio (2008): «El Islam en el arte del Camino de Santiago», La Corónica: $A$ Journal of Medieval Hispanic Languages, Literatures, and Cultures 36.2: 125-143.

Moore, John K. (2015): «Two Religions on One Road to Santiago: Polyethnicity and Syncretism on the Camino in Saint Jacques ... La Mecque», in Samuel Sánchez Sánchez and Annie Hesp (eds.), The Camino de Santiago in the 21st Century: Interdisciplinary Perspectives and Global Views, New York: Routledge, 123-147.

Nordbruch, Götz (2014): Transnational Islam in Interwar Europe: Muslim Activists and Thinkers, New York: Palgrave.

Ramos, María Christina (2011): Literary Cartographies of Spain: Mapping Identity in African American Travel Writing, Ph.D. Dissertation, College Park: University of Maryland.

Roberson, Jennifer (2007): "Visions of Al-Andalus in Twentieth-Century Mosque Architecture», in Mariam Rosser-Owen and Glaire Anderson (eds.), Revisiting al-Andalus, Amsterdam: Brill, 247-271.

SAOud, Rabah (2011): «Al-Hambra Palace and the river of paradise», Muslim Heritage: Discover the golden age of Muslim civilization 18 January, $1+$.

Steves, Rick (2010): Rick Steves' Europe: 605 Granada, Córdoba, and Spain's Costa del Sol, New York: PBS.

Steves, Rick (2018a): «Best of Spain in 14 Days Tour», Rick Steves' Europe. URL: https://www. ricksteves.com/tours/spain-portugal/spain; 24/01/2018. 
Steves, Rick (2018b): «Granada», Rick Steves’ Europe. URL: https://www.ricksteves.com/europe/ spain/Granada; 24/01/2018

Steves, Rick (2018c): «Andalucía», Rick Steves' Europe. URL: https://www.ricksteves.com/europe/ spain/andalucia (subsection «at a glance»); 24/01/2018.

Steves, Rick (2018d): «Granada: Moor than the Sum of Its Parts», Rick Steves’Europe. URL: https:// www.ricksteves.com/watch-read-listen/read/articles/granada-moor-than-the-sum-of-itsparts; 24/01/2018.

Tonkin, Boyd (2013): «The Writing on the Wall», Critical Muslim: 6 (April-June): 203-210.

Velasco de Castro, Rocío (2014): «Las relaciones hispano-marroquíes: fronteras geográficas e ideológicas y su ambivalente papel en la Historia», in Almudena Delgado Larios (ed.), Conflictos y cicatrices. Fronteras y migraciones en el mundo hispánico, Madrid: Dykinson, 183-205. 
